\title{
FRANCIS' IDEA OF THE CHURCH: OUTLINE OF AN ECCLESIOLOGY
}

MARK JOSEPH Z A M M T

\section{ABSTRACT}

In the past eight years, since the election of Francis as the first Latin American pontiff in history, the Church has experienced new manners of being and acting. Even though she has also been in a constant state of aggiornamento, Francis' vision has contributed greatly to this concept of being a perfect image of the ideal Church of Christ (cf. Ecclesiam Suam 10) and a better servant of humanity. The objective of this study is to present an outline of Francis' main ecclesiological concepts, in the awareness that this endeavour can never be completely exhaustive. For this reason, the article is divided into two main sections. In this first one, the bedrocks of his ecclesiological thoughts are studied. These include his Jesuit vocation, the CELAM conferences and vision, and the Argentine theology of the people. In the second section, his main ecclesiological themes are analysed: the people of God, a poor Church for the poor, ecumenism, reform, and an ecological Church.

\section{Keywords}

Church; Ecclesiology; Evangelisation; Francis; Mission; People of God; Reform; Theology of the people

DOI: $10.14712 / 23363398.2021 .5$

$\mathrm{H}_{\mathrm{is}}$ gentle and humble buonasera! with which, upon being elected, he started his Petrine ministry, marked the start of the pontificate which influenced the universal Church with his gestures and attitudes. Despite appearing simple and worldly, they carry a theological and ecclesiological profundity, which significantly changed the pastoral attitudes of the Church.

These words and gestures are based on theological and pastoral options - mainly found in the teachings of Vatican II and Latin 
American theology - serving as the guiding light for the Church today. The ecclesiological vision of Francis is very particular since it never distances itself from the cultural realities of people and the concrete situations in human life. Francis' pontificate is proving to be an evangelical hermeneutic of culture, which assumes the praxis of Jesus as the focus of all theological and pastoral work for the renewal of the Church and society.

This study is divided into two parts. In the first section, Francis' ecclesiological roots are presented: his Ignatian vocation, the CELAM conferences and the theology of the people. By delving into Francis' roots, one may understand today's ecclesiological priorities. In the second section, the salient ecclesiological concepts are analysed. The article finally recapitulates Francis' main objectives for a clearer understanding of his vision of the Church.

\section{Jesuit, Latin American, Argentine: In Search of his Ecclesiological Roots}

Having a Latin American pope after more than 1000 years of European pontificates and the first Jesuit pope in history implies that the Church is being marked with a particular kind of newness, which has not been experienced for many years. This newness includes realities such as the Church's peripheries, mission, and Ignatian discernmentall intimately bound in the person of Francis. All of these theological themes find their roots in three experiences which greatly influenced the personality of Bergoglio: his Jesuit vocation, the CELAM conferences, and the Argentine theology of the people.

\subsection{The Ideal of St Ignatius}

Pope Francis' Jesuit formation, influenced by the Spiritual Exercises and the reform of heart to which these Exercises aspire, reflects itself in how he perceives reform in the Church. ${ }^{1}$ What are the salient elements of this spirituality, which may help us understand Francis' thoughts? First of all, change is brought about in the Church when her members empty themselves from elements and attitudes which hinder

1 Antonio Spadaro, 'La reforma de la Iglesia según Francisco. Las raíces ignacianas,' in La reforma y las reformas en la Iglesia, eds. Antonio Spadaro and Carlos María Galli (Santander: Sal Terrae, 2016), 33-50, 36. 
her mission. In his homily to his fellow Jesuits on the 3rd of January 2014, we can read:

Each one of us, as Jesuits, who follow Jesus should be ready to empty himself. We are called to this humility: to be 'emptied' beings. To be men who are not centred on themselves because the centre of the Society is Christ and his Church. And God is the Deus semper maior, the God who always surprises us. And if the God of surprises is not at the centre, the Society becomes disoriented. Because of this, to be a Jesuit means to be a person of incomplete thought, of open thought: because he thinks always looking to the horizon which is the ever greater glory of God, who ceaselessly surprises us. And this is the restlessness of our inner abyss. ${ }^{2}$

This implies an emptying of self in favour of the greater mission of the Church, with the aim of acquiring a universal vision in readiness to serve in any part of the world. ${ }^{3}$

Secondly, discernment is fundamental to Francis. The late philosopher, theologian, and friend of Bergoglio, Juan Carlos Scannone, describes him as 'governing through discernment'. The Ignatian spirituality is totally grounded in history and in dialogue with culture. For Francis, a correct ecclesial discernment is lived when discerning one's interior experience while journeying in history and dialoguing with reality. ${ }^{5}$ In other words, it means discerning God's will in the daily circumstances of one's life and in the life of the Church.

Thirdly, this implies openness to reality. Discernment and reform necessitate an attitude open to all possibilities, which aids historical processes to arrive at their objective of reform. Francis' style is based on listening and dialogue with people, understanding reality, and engagement in the lives of the people. Following the same spirit of the Exercises of openness to God and to discernment, Francis prefers to use processes in his manner of leading the Church. He advances and decides at par with the whole Church. ${ }^{6}$

\footnotetext{
Pope Francis, Homily, (Rome, 3 January 2014), https://bit.ly/3d3HxiB.

Spadaro, 'La reforma de la Iglesia según Francisco,' 36.

Juan Carlos Scannone, El papa del pueblo. Conversaciones con Bernadette Sauvaget (Madrid: PPC, 2017), 14.

Spadaro, 'La reforma de la Iglesia según Francisco,' 37.

Scannone, El papa del pueblo, 30.
} 
Fourthly, his idea of processes includes encountering limits and conflicts as part of the spiritual journey. ${ }^{7}$ His method of graduality and of accepting limits belongs to his manner of humanising society, which opens up to the greater glory of God. At the same time, his idea of historical processes also tackles temptations and problems within the Church. These he confronts with the vision he has of reality, which comes from the meditation of the two standards of St Ignatius, which involves the battle between good and evil. ${ }^{8}$

Furthermore, he owes great inspiration to the Jesuit saint Peter Faber, whom he considers as an exemplar and model not only of a profound interior life but also of structural reform. ${ }^{9}$ We may highlight four elements from Faber's spirituality and life which influenced Bergoglio and marked his being.

Firstly, Faber's Ignatian ideal of the spirituality of journeying influenced Bergoglio's notion of journeying and encounter. In particular, he affirms:

In the personal experience of God, I cannot do without the journey. I would say that God is found walking, searching for him and allowing oneself to be searched by Him. They are two paths that meet ... That is why I say that my experience with God occurs along the way, in the search, to let Him search for me. ${ }^{10}$

Secondly, Bergoglio owes to Faber his spirit of discernment, a crucial element within the Ignatian vocation and a guide for the Bergoglian pontificate. ${ }^{11}$ Discernment may be supported by living the Ignatian maxim non coerceri maximo, sed contineri minimo divinum est. ${ }^{12}$ In other words, it means not to pose any limit to that which is great, while keeping at heart that which is small and simple. This implies showing greatness through the daily living of the mundane moments, giving value to everything in the light of the kingdom of God. In a spiritual

\footnotetext{
Spadaro, 'La reforma de la Iglesia según Francisco,' 41.

Ibid., 43.

9 Santiago Madrigal Terrazas, 'Fundamentos teológicos de la reforma eclesial en el proyecto del Papa Francisco,' in La reforma y las reformas en la Iglesia, Instituto Teológico Compostelano (Santiago de Compostela, 2017), 353-387, 385.

10 Francis as quoted by Madrigal Terrazas, 'Fundamentos teológicos de la reforma eclesial,' 385.

11 Ibid., 386.
}

12 Ibid. 
conference given in 1981 in Buenos Aires, Bergoglio describes this maxim as showing interest in small things while not being fearful of what is great. ${ }^{13}$ This maxim can be easily felt in Evangelii Gaudium's [EG] principle that the whole is superior to the part.

Thirdly, Faber was a man who lived the joy of the Gospel. His entire spiritual life reflected the beauty of God's word. In EG 171, we encounter Faber's phrase 'time is God's messenger,' which serves, in a way, as the basis of Francis' other principle that time is greater than space. The joy of the Gospel is lived in time, the place where God's experience is lived and hoped for.

\subsection{CELAM Conferences: The Awakening of the Latin American Ecclesiology}

Francis is not only a Jesuit but also a Latin American Jesuit. To understand him, we must also analyse which salient ecclesial moments of the continent marked both the Pope and the Church's mission.

The CELAM conference of Medellin (1968) was a crucial experience in Latin America since it gave an important thrust to the evangelising mission for the Church in this continent by introducing Vatican II to this continental Church with an attitude of compromise, in favour of liberation of the poor. The Puebla conference (1979) assumed the call for the evangelisation of culture, which Evangelii Nuntiandi [EN] (1975) had presented, and made it the central vocation of the pastoral work of the Church. Mission is viewed as the relationship between evangelisation, liberation, and culture. ${ }^{14}$

These former conferences are the foundation of the Argentine theology of the people. However, Aparecida [DA] (2007) is the CELAM conference which mostly influenced Bergoglio, due to his active involvement in the redaction of its final document. This conference gave a new motivation to the Latin American Church for it to be in a permanent state of mission, strongly favourable to pastoral conversion by means of retrieving the sense of discipleship with Jesus Christ in order to be able to communicate this life of Christ with others (DA 368). For Bergoglio, this conference was the impetus of a vocation to embrace a Church which goes forth to meet the world, especially those who are

13 Ibid.

14 Carlos María Galli, 'En la Iglesia sopla un viento del sur. La novedad de América Latina en la nueva evangelización. Diálogo con el Instrumentum laboris para el Sínodo de 2012,' Teología 108 (2012): 101-172, 130. 
considered the least. ${ }^{15}$ To delve into the document of Aparecida actually means to enter into the heart of Francis' reaching out to the world, especially to the peripheries, and into his interest in mission. ${ }^{16}$

Hence, we may affirm that Francis' idea of the Church reform and missionary concept of the Church which goes forth find their roots not only in Vatican Council II but in a special way in the Latin American manner of appropriating the council's teaching in Medellin, in Puebla, and in Aparecida. ${ }^{17}$

\subsection{The Theology of the People: Bergoglio's Theological Roots}

Francis' theology forms part of the branch of the theology of liberation, which focuses on the praxis of the people. This Argentine theology, also called theology of the people, ${ }^{18}$ highlights the integral and evangelical character of liberation, which is pursued in the culture of the people through the evangelisation of their culture. This theology distinguishes itself from liberation theology in two main elements: firstly, the centrality of the role of the people and popular praxis; secondly, the importance of culture. Therefore, the people and culture are the two pillars of the Argentine theology of the people and the way in which an integral liberation can be achieved. A definition of people and their culture from this theology may help us comprehend better Francis' thoughts on these themes in his idea of the Church because he is 'son of the theology of the people'. ${ }^{19}$

In the theology of the people, people is a central theme and includes its own history, culture, and beliefs. In other words, the people are 'a community of men gathered on the basis of the participation of the same culture and that, historically, realize their culture in a determined political will or decision', ${ }^{20}$ a definition based upon the vision of the Argentine episcopal document of San Miguel (1969), which serves as the basis of the main elements of the theology of the people. A people

\footnotetext{
Ibid., 149.

Madrigal Terrazas, 'Fundamentos teológicos de la reforma eclesial,' 369.

Santiago Madrigal Terrazas, El giro eclesiológico en la recepción del Vaticano II (Santander: Sal Terrae, 2017), 298.

18 See Juan Carlos Scannone, La teología del pueblo. Raíces teológicas del papa Francisco (Santander: Sal Terrae, 2017), 16-20.

19 Ibid., 15.

20 Lucio Gera, 'Pueblo, religión del pueblo e Iglesia,' in Escritos Teológico-Pastorales de Lucio Gera I. Del Pre concilio a la Conferencia de Puebla (1956-1981), eds. V.R. Azcuy, C.M. Galli and M. González (Buenos Aires: Ágape, 2006), 717-744, 724.
} 
is formed where there is the common goal of unity between persons who share a common culture, history, and politics and in which the Gospel values are already present. The strength of the people is not encountered in its political objectives, like other branches of liberation theology, but rather in its culture and faith, which makes it subject to its own promotion and liberation.

On the other hand, in the theology of the people, culture is the activity which places the person in relation to other realities (God, nature, and other persons) with the scope of one's realisation..$^{21}$ It is the style of life, which characterises one's manner of living by particular values. Thus, culture has an active dimension (the cultivation of culture) and an objective (the person and the people realise themselves). Culture is a historical reality, deeply immersed in history, since the realisation of the person, of the people, and of culture as a whole is achieved in time. ${ }^{22}$ The people creates its own manner of living, based upon particular values which reflect the being of the particular people and which help it reach its realisation. ${ }^{23}$

The themes of people and culture are united by the option for the poor, central to Latin American theology. The poor are the ones who conserve the fundamentals and values of the culture of a people, whose projects coincide with the historical project of justice and peace, which the Latin American continent strives for. ${ }^{24}$ Thus, the preferential option for the poor, which began in Medellin and was crystallised in Puebla, finds its necessary strength in the evangelisation of culture, which the Argentine theologians reflect upon in their theology of the people.

\section{An Outline of Francis' Ecclesiological Themes}

Heretofore the three main elements which influenced Bergoglio in his vision of the Church have been briefly presented. We shall now attempt to analyse the main themes of his ecclesiology that are a result of these elements. The scope is not to conduct an exhaustive investigation of his ecclesiology but rather to present an outline of the main

\footnotetext{
21 Lucio Gera, 'Puebla: evangelización de la cultura,' in Escritos Teológico-Pastorales de Lucio Gera I, 817-839, 823.

22 Lucio Gera, 'Identidad cultural y nacional,' Sedoi 73 (1984): 5-40, 16.

23 Lucio Gera, 'Cultura y dependencia a la luz de la reflexión teológica,' in Escritos Teológico-Pastorales de Lucio Gera I, 605-625, 606.

24 Scannone, La teología del pueblo, 20.
} 
concepts, which serve as guiding force for his vision of Church and manner of leading the Church today. These include his gestures, his idea of people of God, the poor Church of the poor, the ecumenical endeavour, reform, and finally his idea of an ecological Church.

\subsection{An Ecclesiology of Gestures}

Francis' gestures already indicate a new way of presenting the Church. They complement and explain more vividly his principal theological themes. This is because 'the way he says things, the how, the gestures, contain a strong symbolic value, ${ }^{25}$ which help understand deep theological concepts and through which Francis creates a sort of incarnated theology. The following are the main gestures that have contributed towards a presentation of the Church that belongs to the people and serves them:

i) The attention given to the poor: His whole life and pontificate are marked with particular attention given to the most vulnerable and marginalised. In fact, every meeting with the faithful and every apostolic journey includes encounters with such realities. His own choice of name reflects this priority of poverty given to his pontificate and to all the Church.

ii) The female face of the Church: Francis also gives priority to women, not only by nominating women within the various structures of the Holy See, but also by being close to their sufferings. These include visiting female prisons, denouncing labour exploitation and abuse, and being close to the victims of mafia.

iii) Close to migrants: Francis's gestures invite the Church to hold in her bosom migrants and denounce their suffering. Two of these include his apostolic visit to the migrant camps in the Italian island of Lampedusa in 2013 and his moment of prayer at the U.S.-Mexico border in 2016 and thus presenting a Church which is against the building of walls of segregation but in favour of integration of nations.

iv) Simplicity: Francis' simplicity of life, simplicity of clothes, choice of a car, and home apartment all present a model for all Christians to live a simple but intense life as people of God.

v) Close to the people: It is not the first time that we see Francis taking a selfie with groups of people, or rejoicing over something typically

${ }_{25}$ Scannone, El papa del pueblo, 71. 
Argentine donated to him, or even joking with visitors, or surprising many with his phone calls. All these actions reflect his will of being a 'normal' person journeying with others and sharing everything that belongs to humanity by being close to people. His daily mass in Casa Santa Marta also reflects a pontificate, which is open to the faithful and being with them.

Whilst appreciating the gestures of every pontiff, the election of Pope Francis brought about a style of gestures that also carry pedagogical meaning since they represent an ecclesial lifestyle which Francis is trying to instil in the daily lives of the faithful and in the Church institution. Nevertheless, gestures are accompanied by words, which together present an outline of an ecclesiology more holistically, as we shall now analyse.

\subsection{The 'Holy, Faithful People of God': The People of God in the Peoples of the World}

Francis' understanding of people of God is formed by two essential elements: the teachings of Vatican II and the idea of the theology of the people. In line with his predecessors, Francis continues with this search for ecclesiological identity especially in his programmatic Evangelii Gaudium, which highlights the vision of his pontificate and idea of the Church based upon Lumen Gentium [LG] (cf. EG 17).

In an interview by Antonio Spadaro, the new elected Pope Francis immediately expresses his idea of people of God:

The image of the church I like is that of the holy, faithful people of God. This is the definition I often use, and then there is that image from the Second Vatican Council's 'Dogmatic Constitution on the Church' (No. 12). Belonging to a people has a strong theological value. In the history of salvation, God has saved a people. There is no full identity without belonging to a people. No one is saved alone, as an isolated individual, but God attracts us looking at the complex web of relationships that take place in the human community. God enters into this dynamic, this participation in the web of human relationships. The people itself constitutes a subject. And the church is the people of God on the journey through history, with joys and sorrows. ${ }^{26}$

26 Pope Francis, Interview by Antonio Spadaro, (Vatican, 19 August 2013), https://bit $.1 \mathrm{y} / 3 \times 2 \mathrm{c} 9 \mathrm{Jj}$. 
These words totally condense the teaching of the Argentine theology of the people on the people of God, and this theme forms the foundation of Bergoglio's ecclesiology. What salient elements can we extract from this affirmation regarding his idea of people of God, which crystallises itself in EG?

First of all, Francis' idea is very conciliar, based on LG 12. This constitution highlights the common priesthood of everyone, before any ministerial division or service, as an essential element of the Church. It presents the election of the new people of God, the Church, guided by Christ as its head, and called to love and be missionary to all people. ${ }^{27}$ This same doctrine is very much the basis of EG, in which this conciliar doctrine is linked to the category of people as understood in Argentina. Francis' intention is to enhance the relation between the mystery of the Church originating in the Trinity and the concrete historical and cultural forms of the people of God in the world.

Secondly, by including the history of salvation in his definition, he is showing the importance of history, especially since God reveals himself in history, which is the reality in which the people of God is journeying. Through the discernment of the signs of the times, one may capture the salvific presence of God in the events of history, the way He acts in history, where He is conducting it and what He reveals to it.

Moreover, and in a third setting, history includes all that forms the people: the journey of faith, political endeavours, economic progress, and cultural changes. Since the Church is formed in history and shaped by culture and, as Francis affirms, 'grace supposes culture' (EG 115), this implies that God's salvation is experienced and passes through the fabric that builds up the community. Essential to this fabric, according to the Argentine Pope, is popular religiosity, which is 'a spirituality incarnated in the culture of the lowly' (EG 124 \& DA 263). It is a spirituality pregnant with symbols, which already holds the seeds of the Gospel, and the place in which God's presence can be discerned. Hence, culture is a constitutive element of the people of God on earth. Francis holds that the 'universal Church is a communion of particular inculturated churches and, indirectly, of peoples and cultures. ${ }^{28}$ The catholic dimension of the Church is fully realised in the unity of this diversity.

27 Gérard Philips, La Iglesia y su misterio en el Concilio Vaticano II. Historia, texto y comentario de la constitución Lumen gentium, vol. 1 (Barcelona: Editorial Herder, 1968), 171-172.

28 Galli, 'En la Iglesia sopla un viento del sur,' 116. 
We perceive Francis' appreciation of diversity in his words: 'beauty of her varied face' (EG 116), 'multifaceted and inviting harmony' (EG 117), and 'cultural diversity is not a threat to Church unity' (EG 117). Fourthly, Francis thinks of the Church as a concrete human community of mutual influence and interdependence. Conceiving the Church in this manner implies thinking of the concrete realities of the community together with the need of including and integrating every person within the whole group. The role of the local Church becomes crucial here since it serves as the ideal integrating community within a particular geographical territory. Its role is important not only on the level of human aid but also on an evangelising level owing to the fact that it is 'the primary subject of evangelisation, since it is the concrete manifestation of the one Church in one specific place' (EG 30).

In fifth place, within this community, the people are a collective subject. We immediately sense this role of the common priesthood of the people of God when he asks their blessing in St Peter's Square upon being elected as pontiff. Moreover, this means that the people are not only the subject of their own history and culture, but also of evangelisation, that is, of the Church's mission: 'the entire people of God proclaims the Gospel' (EG 111). In the theology of the people, the poor amongst the people are the authentic subjects of evangelisation since the presence of God, who chooses to direct his love to them in a preferential manner, can be encountered in them. They are also living signs of evangelical fraternity and solidarity. ${ }^{29}$

\subsection{A Poor Church for the Poor: 'Called to Care for the Vulnerable of the Earth' (EG 209)}

Francis' social reflections on the reality of poverty are a continuation of Paul VI's Evangelii Nuntiandi (EN 29-39) and Populorum Progressio, which teach the relation that must exist between evangelisation and the social commitment of the Church. ${ }^{30}$ Moreover, similarly to the initiatives in Medellin and Puebla, Francis continues with the call of making the Church conscious of the structural injustices, which create poverty.

If the Council represents the Church reaching out to the world, Medellin is the great breakthrough of the Church that reaches out

\footnotetext{
29 Lucio Gera, 'San Miguel, una promesa escondida,' in Escritos Teológico-Pastorales de Lucio Gera II. De la Conferencia de Puebla a nuestros días (1982-2007), eds. V.R. Azcuy, J.C. Caamaño and C.M. Galli (Buenos Aires: Ágape, 2007), 271-295, 289.

30 Madrigal Terrazas, 'Fundamentos teológicos de la reforma eclesial,' 377.
} 
to the poor. Furthermore, Puebla then crystallises the vocation of the Church in favour of the poor: "we affirm the need for the conversion of the whole Church for a preferential option for the poor, with a view to their integral liberation' (DP 1134). Francis continues with the incomplete agenda regarding the poor of Vatican II, of Medellin, and of Puebla to move the issue of poverty from the peripheries towards the centre of the Church and of society. ${ }^{31}$

Involvement with the poor does not mean simply giving alms, but rather a choice based on God's example of becoming poor for the sake of humanity, which serves as a dimension for the life of the Church. When delving into the theme of the poor, the Church is encountering God's face whose love commences from the poor..$^{32}$ Therefore, a Church of the poor implies serving them whilst at the same time learning from the lives of the poor, from their participation in the sensus fidei, and from their experience of the suffering Christ (cf. EG 198). This is because the life of the poor and their expressions of piety are a theological locus ${ }^{33}$ of the experience of God and coordinates of the new evangelisation (cf. EG 126). They are criteria for the Church's discernment of the authenticity of her life and mission (cf. EG 195).

He addresses two important issues in order to be a Church of the poor and for the poor ${ }^{34}$ :

i) Social inclusion of the poor: EG 186 explicitly shows that the Church's mission in favour of the poor must start from 'our faith in Christ, who became poor, and was always close to the poor and the outcast'. God's mercy is authentically experienced in the preferential option of the poor of the Church, to include both their liberation as well as the promotion of their lives. Moreover, working in favour of the poor does not only mean making changes to structures but also to the culture of the people (cf. EG 188).

ii) Dialogue in favour of social peace and friendship: A Church for the poor implies striving to integrate the poor into society resulting in social peace and friendship. This theme, discussed in EG 217-237

31 Scannone, La teologia del pueblo, 191.

32 Juan Carlos Scannone, 'Encarnación, kenosis, inculturación y pobreza,' in La reforma y las reformas en la Iglesia, eds. Spadaro and Galli, 497-521, 504.

33 See Jacob Phillips, 'A bride bedecked with her jewels. Understanding inculturation and popular piety as la locus theologicus in Evangelii gaudium,' in Pope Francis, Evangelii gaudium and the renewal of the Church, eds. Duncan Dormor and Alana Harris (New York: Paulist Press, 2017), 112-131.

34 Madrigal Terrazas, 'Fundamentos teológicos de la reforma eclesial,' 378-379. 
and in Fratelli Tutti 198-224, fosters a spirit of respect for the common good, as well as creates a culture of encounter ${ }^{35}$ (cf. EG 220) which goes beyond individualism in favour of the integration of every person within the community.

Both these issues present a Church which unites her evangelisation with the need for justice and liberation in the world.

His vision of a poor Church for the poor builds upon his concept of 'experiences of communitarian salvation' (Laudato Si [LS] 148). In his ideas regarding an ecology of daily life, described in LS, the Argentine Pope focuses on the daily life of the people as the place where change can really start: 'Authentic development includes efforts to bring about an integral improvement in the quality of human life, and this entails considering the setting in which people live their lives' (LS 147). This implies that communitarian salvation occurs in the culture of the community.

What is specific to the theology of the people and to Francis is that communitarian salvation can originate from the poor themselves since 'many people in these conditions are able to weave bonds of belonging and togetherness which convert overcrowding into an experience of community in which the walls of the ego are torn down and the barriers of selfishness overcome' (LS 149). These bonds of belonging and sharing of life create the fabric for a communal Church in which salvation may as of now be experienced in the form of liberation through human living experiences.

\subsection{The Priority of Ecumenism}

Francis appropriates the conciliar theme of ecumenism as an ecclesiological priority: 'the pursuit of full Christian unity remains a priority for the Catholic Church, and thus it is daily one of my chief concerns' ${ }^{36}$ His idea of the culture of encounter and of dialogue partly includes the ecumenical mission of the Church. Francis motivates in favour of an ecumenism of journeying together, which necessarily includes the other Christian churches. He states in one of his ecumenical discourses:

35 See Julio Martínez, La cultura del encuentro. Desafio e interpelación para Europa (Santander: Sal Terrae, 2017).

36 Pope Francis, Letter to the participants in the plenary assembly of the Pontifical Council for Promoting Christian Unity for the 50th anniversary of the Decree Unitatis Redintegratio (Vatican, November 20, 2014) as quoted by Rodrigo Polanco, 'El Papa Francisco y el ecumenismo del camino,' Medellín 169 (2017): 631-674, 634. 
Often, we think that the ecumenical endeavour is only for theologians. For this reason, it is important that theologians study, come to agreements, and express disagreements; this is very important. However, in the meantime, ecumenism is created on the path. In walking with Jesus, it is not with my Jesus versus your Jesus, but our Jesus. The path is simple: it is made with prayer and with the help of others. ${ }^{37}$

It is a missionary journey, which inevitably involves openness to the other on all levels of ecclesial structures and of all the people of God.

His ecumenical thoughts include the following four dimensions: ${ }^{38}$

i) On a theological level, he insists on returning to the Sacred Scriptures and to the hierarchy of truths (cf. UR 11) so that 'if we concentrate on the convictions we share, and if we keep in mind the principle of the hierarchy of truths, we will be able to progress decidedly towards common expressions of proclamation, service and witness' (EG 246). Even though all truths proceed from the same divine fount, some express more directly than others the heart of the Gospel with the scope of favouring a more integral perspective of truths and their hierarchy. ${ }^{39}$ Francis conceives theological dialogue as part of the ecumenical mission of journeying together as a whole Church of Christ. ${ }^{40}$ Being influenced by the theology of the people -from which perspective we can better understand his four principles: time is greater than space, unity prevails over conflict, reality is more important than ideas, and the whole is greater than the part-Francis also considers the ecumenical endeavours within this framework and is influenced by these tensions. Hence, taking all the time needed to work towards unity between churches, always choosing the way of unity instead of conflict, encountering situations and people rather than ideas or theories, and striving to perceive the larger scenario rather than specific problems all pertain to Francis' idea of ecumenism. ${ }^{41}$

\footnotetext{
Pope Francis, Address to the participants in the conference of secretaries of 'Christian World Communions,' (Vatican, October 12, 2016) as quoted by Polanco, 'El Papa Francisco y el ecumenismo del camino,' 636.

38 Elias Wolff, 'Through an exchange of gifts, the Spirit can lead us ever more fully into truth and goodness,' Medellin 168 (2017): 515-530, 519-521.

39 Madrigal Terrazas, 'Fundamentos teológicos de la reforma eclesial,' 372.

40 Polanco, 'El Papa Francisco y el ecumenismo del camino,' 663.

41 William Henn, 'Intercambio de dones: la recepción de los frutos del diálogo y la reforma de la Iglesia,' in La reforma y las reformas en la Iglesia, ed. Spadaro and Galli, 399-423, 405.
} 
ii) On an ecclesiological level, Francis appreciates the ecclesial pluralism which exists today even outside Catholic structures:

If we really believe in the abundantly free working of the Holy Spirit, we can learn so much from one another! It is not just about being better informed about others, but rather about reaping what the Spirit has sown in them, which is also meant to be a gift for us. To give but one example, in the dialogue with our Orthodox brothers and sisters, we Catholics have the opportunity to learn more about the meaning of episcopal collegiality and their experience of synodality. (EG 246)

Francis chooses the model of the local church to show how the Gospel is incarnated in a specific culture and place. This model presents a Church governed by the many, rather than centralised, and within this synodality and collegiality, he includes other non-Catholic churches: 'we are pilgrims journeying alongside one another' (EG 244).

iii) On a missionary level, decentralisation and pastoral conversion have proven to help the Church remain faithful to the spirit of the Gospel, especially when she opens up to differences in ecclesial traditions and ecumenical denominations. Mission and the common good of humanity, are issues which serve as binding forces between all Christian churches. The perennial issues regarding humanity and the social dimension of mission serve as areas of encounter between the churches in favour of social inclusion, social justice, and social peace.

iv) On a spiritual level, Francis also invites the whole Church to be able to exchange spiritual gifts with other churches as part of its pastoral conversion in order to be a more perfect image of the one undivided body of Christ: 'through an exchange of gifts, the Spirit can lead us ever more fully into truth and goodness' (EG 246). Moreover, he insists that prayer lies at the basis of this search for unity since it creates the necessary spiritual bonds which help create other external bonds. ${ }^{42}$

Additionally to these four dimensions, Francis understood the reduction of ecclesial autoreferentiality as a manner of opening itself

42 Pope Francis, Speech at the Ecumenical Encounter and Prayer for Peace (Armenia, 25 June 2016), https://bit.ly/3j41F7O. 
up not only to its margins but also to other Christian churches. Moreover, his own manner of living the papacy also reflects a shift towards openness and service to the Church, of a collegial idea of authority-not only through the importance he gives to the Synod of Bishops but also through the style of ecclesial governance with the Council of Cardinal Advisers-and at the service of the unity of Christians (cf. EG 32 \& 244-246).

By way of conclusion of this section, how can the Church find its original unity among Christians? Francis contemplates this unity in terms of the image of the polyhedron:

Here our model is not the sphere, which is no greater than its parts, where every point is equidistant from the centre, and there are no differences between them. Instead, it is the polyhedron, which reflects the convergence of all its parts, each of which preserves its distinctiveness (EG 236).

Francis favours both unity and diversity in ecumenism and, hence, this endeavour actually means that the diversity between the churches is harmonised with the power of the Holy Spirit until it reaches its unity.

\section{5 'Francis, Go Rebuild my House': Ecclesial Reform}

Francis' idea of reform does not find its motivation in anthropology, that is, in an explanation of a deviant humanity, but rather in a sick ecclesiocentrism, or better explained, in a Church that closes upon and within itself, thus distancing itself from the world. ${ }^{43} \mathrm{He}$ affirms:

We must recognize that if part of our baptized people lack a sense of belonging to the Church, this is also due to certain structures and the occasionally unwelcoming atmosphere of some of our parishes and communities, or to a bureaucratic way of dealing with problems (EG 63).

An authentic reform of the Church strives for perfection on different levels in following the Lord. This can be crystallised in the following three bergoglian reforms:

43 Amparo Alvarado Palacios, 'Revolución de la ternura: un nuevo paradigma eclesial en el pontificado de Francisco,' Revista Albertus Magnus 10/2 (2019): 165-184, 171. 


\subsubsection{Reform of the Heart: The Revolution of Tenderness}

Each authentic reform commences in spirit, in virtues, and in attitudes. Accordingly, Francis' reform of the Church commences from the loving mercy of God, which transforms attitudes and instils new practices. His logic of mercy influences the manner reform is conducted in the Church, and his tenderness revolution is a force which integrates people in the Church and which includes everyone. ${ }^{44}$ Mercy, therefore, is the basic criterion with which the Church must read society and undergo reform.

Francis' ecclesiology is completely conciliar: both his teachings and his spirit of doing things are motivated by the same spirit and vision of Vatican Council II. Paul VI concluded Vatican II affirming: 'The old story of the Samaritan has been the model of the spirituality of the council. A feeling of boundless sympathy has permeated the whole of it. The attention of our council has been absorbed by the discovery of human needs. ${ }^{45}$ Vatican II was a crucial opportunity for the Church to open her doors and reread her mission from an openhearted and merciful viewpoint, in order to meet the needs of contemporary society. This same conciliar spirituality of the Good Samaritan, that is, of mercy, is Francis' own in his reforming mission in the Church which is at the service of humanity. ${ }^{46}$ Upon crossing St Peter's door at the opening of the jubilee of mercy, he recalls once again this spirituality and vision: 'May our passing through the Holy Door today commit us to making our own the mercy of the Good Samaritan. ${ }^{97}$ Converting into a Samaritan Church, which walks 'the way of mercy' (Misericordiae Vultus 10-12), is how she may perfectly express her mission of going forth to the world, how she can always be first in loving (cf. EG 24) and how she may be credible in the world.

Francis' idea of the revolution of tenderness centres itself on the joy of Christ. This centrality of the Gospel is the fount of ecclesial reform, a vision presented in his EG, in which document the joy of the Gospel

44 Carlos María Galli, 'Revolución de la ternura y reforma de la Iglesia,' Medellín 170 (2018): 73-108, 75. See also Walter Kasper, Pope Francis' revolution of tenderness and love (New York: Paulist Press, 2015), 31-36.

45 Paul VI, Address during the last general meeting of the Second Vatican Council, (7 December 1965), https://bit.ly/2TWdaDI.

46 Galli, 'Revolución de la ternura y reforma de la Iglesia,' 80.

47 Pope Francis, Homily at the opening of the holy door, (Vatican, 8 December 2015), https://bit.ly/3gJIY7T. 
runs parallel to the mission of mercy. ${ }^{48}$ 'The delightful and comforting joy of evangelizing' (EN 80), described by Paul VI, crystallises itself in Bergoglio's spirit of reform due to the fact that it is this joy which creates and nourishes ecclesial communities of missionary disciples. This bergoglian reform starts from the grassroots, from the lives of the poor and suffering, and from the presence of the Church in the concrete situations of life. This implies two essential elements: the social dimension of the ecclesial mission and inculturation of the Gospel. Firstly, this denotes a good understanding of the situations of the people and defending their basic human needs and rights. Secondly, inculturation means appreciating the diversities of cultures and the relevance of the Gospel to all cultures around the world. Moreover, his exhortation Amoris Laetitia concretely manifests this spirit of tenderness and pastoral priority to accompany, discern, and integrate the many fragile Christians who suffer difficult moments in family life (cf. AL 307-312).$^{49}$ On these lines, we may affirm that, in the bergoglian ecclesial mission, this logic of tenderness necessarily includes compassion and integration.

\subsubsection{Reform of Structures: The Way of Synodality}

Central to his ecclesiology and to his reform of ecclesial structures is his idea of an inverted pyramid, also referring to a synodal Church that is 'the principle which structurally configures the Church in a constant movement of missionary outgoing' ${ }^{50}$ Due to the influence of the theology of the people, Francis inverts Church structures in order to place the whole people of God, and in a special way the local church (cf. EG 30), as the main actor in the mission of the Church. In his emblematic discourse on the 50th anniversary of the institution of the Synod of Bishops, Francis describes synodality of the people of God as the 'constitutive element of the Church'. ${ }^{51}$

Within this context, what does his image of the inverted pyramid signify? In fact, synodality does not really represent a new way of understanding the Church and its mission, since it has always accompanied its history, but it is rather a concrete and contemporary application of

\footnotetext{
48 Galli, 'Revolución de la ternura y reforma de la Iglesia,' 86.

49 Ibid., 91.

50 Santiago Madrigal Terrazas, 'La eclesiología pastoral del Papa Francisco: releyendo Evangelii gaudium,' Misión Joven 492-493 (2018): 27-52 at 49.

51 Pope Francis, Address on the ceremony commemorating the 50th anniversary of the institution of the Synod of Bishops, (Vatican, 17 October 2015), https://bit.ly/3d3g28J.
} 
the vision of LG which places the people of God as a doctrinal priority before the hierarchical division of the Church. This inverted order, represented by the inverted pyramid, explains the fact that the hierarchical ministry of the Church is at the service of the communion of the people of God. ${ }^{52}$ In practical terms, this implies a Church which listens, dialogues, learns, and cooperates within itself (faithful people, episcopal college, bishop of Rome) and with all humanity in order to encounter the way of true growth.

In practical terms, this denotes a conversion of hearts and attitudes not only of all the people of God but also within the institution of the Church, represented explicitly in the reform of the Holy See's Curia. ${ }^{53}$ Together with this reform one may also include an increased appreciation of the role of the laity, going beyond clericalism and centralisation, recognising the importance of every local bishop and Episcopal Conference $^{54}$ in the universal Church, facilitating the canonical process of nullity of marriage ${ }^{55}$, creating a culture of transparency and safeguarding of the most vulnerable, reforming the papacy, and exalting the role of women in the Church. ${ }^{56}$ Finally, the objective of these structural reforms is to create a missionary Church rather than a Eurocentric one. ${ }^{57}$

\subsubsection{The Missionary Transformation of the Church: The Connection between Mission and Reform}

New manners of understanding the Church imply new forms of action on the personal, communal, institutional, and pastoral levels. This is what Francis terms 'the reform of the Church in her missionary outreach' (EG 17), which encounters its roots in the missionary and

52 Galli, 'Revolución de la ternura y reforma de la Iglesia,' 96.

53 See Hugo H. Cappello, 'El papa Francisco y la reforma de la Curia Romana,' AADC 24 (2018): 183-200; Libero Gerosa, ed. La Chiesa in uscita di papa Francesco. Spunti per un rinnovo della missione apostolica (Siena: Edizioni Cantagalli, 2018).

54 See Hector Scerri, The gentle breeze from the peripheries. The evolving role of episcopal conferences (Malta: Horizons, 2018).

55 Gianluca Belfiore, I processi di nullità matrimoniale nella riforma di Papa Francesco (Catania: Studio Teologico S. Paolo, 2017); Montserrat Gas Aixendri, 'La reforma del proceso canónico de nulidad del matrimonio Algunas claves de lectura desde el magisterio del Papa Francisco,' Revista Jurídica Digital UANDES 1 (2017): 85-100.

56 Galli, 'Revolución de la ternura y reforma de la Iglesia,' 100.

57 Carlos Schickendantz, 'Las conferencias episcopales: 'Este deseo no se ha realizado plenamente' (EG32),' in La reforma y las reformas en la Iglesia, eds. Spadaro and Galli, 375-395, 383. 
pastoral conversion proposed by the document of Aparecida (cf. DA 365-372) ${ }^{58}$ For the Argentine pontiff, his vision of a synodal Church is connected with his ecclesiology of missionary disciples. ${ }^{59}$ However, the novelty in such a perennial vocation of the Church is the constant and permanent renovation of mission and pastoral structures. Therefore, reform is understood as the never-ending ecclesial attitude of missionary conversion, which in turn motivates the reform of ecclesial structures, and whose starting point is always the peripheries of the Church.

Pastoral conversion ${ }^{60}$ implies a Church which goes forth to humanity in ever-renewed ways as a natural consequence of the encounter with the Gospel. At the basis of this vocation is Jesus' missionary sending of his disciples to the world. It may be appreciated that,

such a kind of missionary approach of the outgoing Church is novel, since for Francis the primacy in the task of the Church is the mission to the peripheries and not so much internal communion, and for this reason when he uses the expression communion, he adds the precise adjective of missionary. ${ }^{61}$

Francis' primary task does not exclude ecclesial communion but directs it in favour of a Church without any boundary or frontier. The foundational principle of the theology of an outgoing Church is the doctrine of the Church as a sacrament, as a clear sign of salvation and ferment in the world. This is in line with GS 45, which states: 'every benefit which the people of God during its earthly pilgrimage can offer to the human family stems from the fact that the Church is the universal sacrament of salvation.' This interaction with the world is the manner how the Church evangelises and remains faithful to the Gospel.

Two images, which vividly describe Francis' idea of pastoral conversion, are mother and hospital. In EG 46-49 he describes the Church as 'a mother with an open heart'. As a mother, she opens up her doors so that everyone may enter, but also so that those inside may go forth to

58 Galli, 'Revolución de la ternura y reforma de la Iglesia,' 97.

59 Santiago Madrigal Terrazas, La sinodalidad en la vida y en la misión de la Iglesia. Texto y comentario del documento de la Comisión Teológica Internacional (Madrid: BAC, 2019), 84.

60 See Instituto Superior de Pastoral, La conversión pastoral (Estella: Editorial Verbo Divino, 2015).

${ }^{61}$ Salvador Pié-Ninot, 'La eclesiología del papa Francisco,' RCatT 43/2 (2018): 503-526, 510. 
encounter others (cf. EG 46). ${ }^{62}$ In AL 291, he describes the Church as 'a field hospital' implying the role of the people of God to accompany, care, and offer a cure for the new and complicated situations of contemporary society. These images show that an evangelised Church is necessarily a missionary Church that goes forth with open arms and a merciful heart.

\subsection{An Ecological Church: The Care for Humanity and for all Creation}

According to Francis, the central task of the Church is to care for God's creation, and in a special way for the most vulnerable. When conceiving a Church and society which are ecologically integral, in his LS, Francis goes beyond the anthropological debate of the $20^{\text {th }}$ century of integral humanism and anthropocentrism, and shifts his sight towards a biopersonalism, which includes the biological (nature) and the biographical (cultural) and hence is trying to tackle the social and environmental crises in a complete manner. ${ }^{63}$ This implies a new way of being the Church today: a biopersonalistic one which assumes the scientific preoccupation regarding the environmental and social crisis and which invites all humanity to tackle it in an integral manner by uniting nature, reason, and culture. ${ }^{64}$ Thus, integral ecology and social justice are united in one unique mission for the reason that Francis understands clearly that human suffering exists at par with the environmental crisis.

Francis favours a Church that not only thinks of an integral humanism which promotes all the dimensions of the person but that also reinvents a humanism caring for the person, the community, and all the natural environment (cf. LS 231). Hence, an integrally ecological Church cares for our common home and likewise for every person and community through social justice.

Without any doubt, here again we encounter the influence of Francis' theology of the people which tries to unite politics, economics, history, culture, and religion in one unique ecclesial option. In this Argentine theology, culture is the style of daily living of the people, characterised by particular values that give meaning to the community. Hence, this

62 Ibid., 516.

63 Agustín Domingo Moratalla, Condición humana y ecología integral. Horizontes educativos para una ciudadanía integral (Madrid: PPC, 2017), 40.

64 Ibid., 57. 
integral ecological manner of being the Church must characterise the daily responsible living of the people. This is what he means when affirming: 'All of this shows the urgent need for us to move forward in a bold cultural revolution' (LS 114), where 'cultural revolution' implies a personal and communitarian transformation of our daily lives in favour of the good of each individual, of the community, and of nature.

\section{By Way of Balance, Always Provisional}

By way of a provisional conclusion regarding Francis' idea of the Church, we may affirm the following as constituting his ecclesiological vision:

i) No new ecclesiology, but a fresher one: Francis does not invent a new Church, but rather builds on Vatican II and his predecessors in favour of a fresher way of being the Church which meets today's needs. His understandable words and gestures continue to show a Church which has always entered into dialogue with society and culture, and is committed to the peripheries. However, his manner of speaking to the world, his invitation of journeying together, of experiencing God's mercy, of encountering the other, as though he were a parish pastor, is perhaps what creates this freshness in the Church and the motivation for the growth of an authentic ecclesial community. ${ }^{65}$

ii) Discerning Church: The basic criterion for discernment is the periphery, from which the Church may understand the totality of reality. An ongoing reform of the Church must start from this pastoral motivation and end with it, in order to be faithful to the Gospel which holds the peripheries at its centre. While remaining the same in essence, the Church as the people of God matures through the ages through the discernment of the signs of the times in order to be the perfect image of this chosen people in the lasting unity of mission and reform.

iii) Evangelising community: The community of disciples (lay and pastors) living in historical and cultural differences are the subjects of evangelisation. This missionary community, or equally well the Church which goes forth, goes beyond a clericalistic Church and is

${ }_{65}$ Diego M. Molina Molina, 'El primer año del papa Francisco,' Proyección 61 (2014): 145-160, 157. 
the central ecclesiological paradigm of Francis. For such a community, mission means taking the initiative to serve, accompanying the suffering of humanity, and celebrating God's lasting presence within it (cf. EG 24).

iv) The pastoral and servant way: The connection between faith and life is crucial for Francis since he presents the mission of the Church and her relationship with God, which is totally ingrained in history. The roots of his pastoral mission involves 'how best to bring the Gospel message to different cultural contexts' (EG 133). ${ }^{66}$ His theological-pastoral way includes both reflection and life of the believer while remaining faithful to the depositum fidei and open to the creativity of discernment. ${ }^{67}$

The Pope's model of the Church is a servant Samaritan Church. In other words, service is the vocation of the missionary disciples of Christ. Moreover, all reform is also undertaken to create a servant Church, which better serves the needs of contemporary society. To be such a servant Church, she holds the Gospel as the nucleus and motivation for continual reform, the result of which being new ways of encountering persons in concrete situations with open doors and heart. $^{68}$

Faculty of Theology

University of Malta

Msida MSD 2080, Malta

mark.j.zammit@um.edu.mt

66 Santiago Madrigal Terrazas, De pirámides y poliedros. Señas de identidad del pontifcado de Francisco (Santander: Sal Terrae, 2020), 283.

Ibid., 285.

68 Molina Molina, ‘El primer año del papa Francisco,' 153-154. 